\title{
Notes on the vocalizations of Northern Scrub-robin (Drymodes superciliaris)
}

Peter Boesman

In the following we briefly analyze and compare voice of the different races of Northern Scrub-robin (Drymodes superciliaris). We also try to quantify the extent of any vocal differences using the criteria proposed by Tobias et al. (2010), as a support for taxonomic review. We have made use of sound recordings available on-line from Xeno Canto (XC).

Comparison of song of the different races:

\section{$\underline{\text { beccarii }}$}

short song: long flat-pitched whistles interspersed with short notes, resulting in a rhythmic delivery:

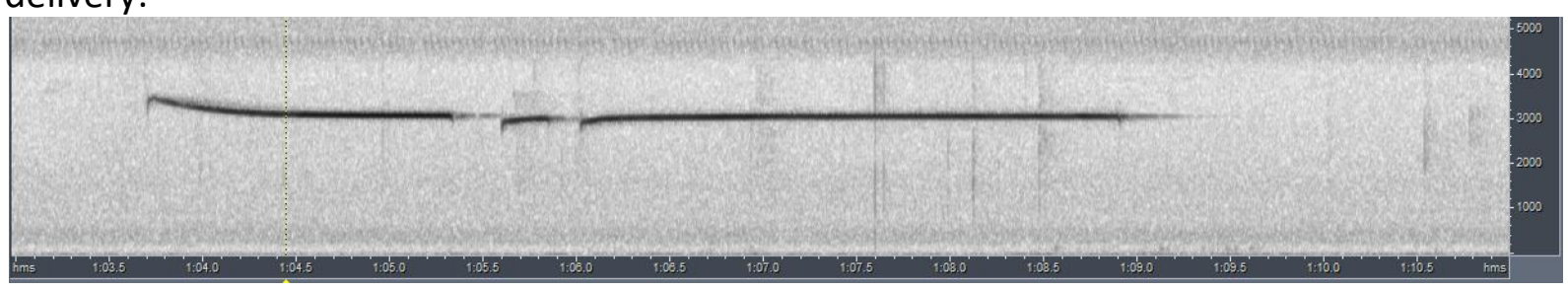

\section{$\underline{\text { nigriceps }}$}

short song: long flat-pitched whistles:

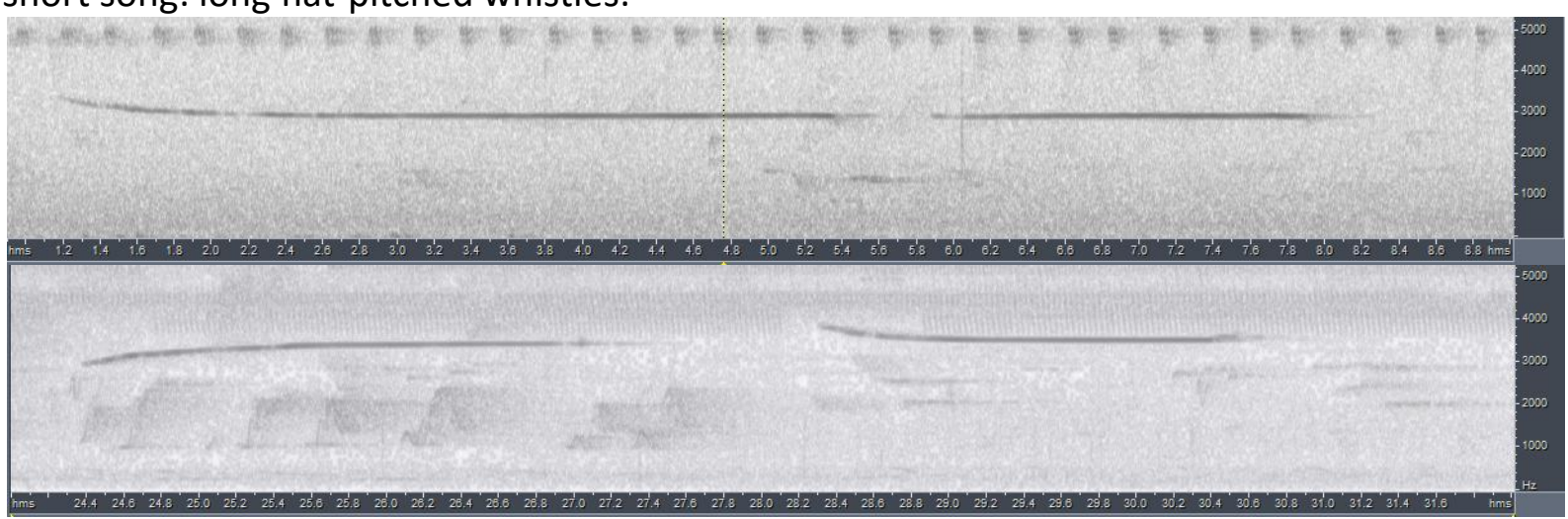

full song (note the different time scale (6x more compressed)!): series of long flat-pitched whistles each slightly lower-pitched than previous:

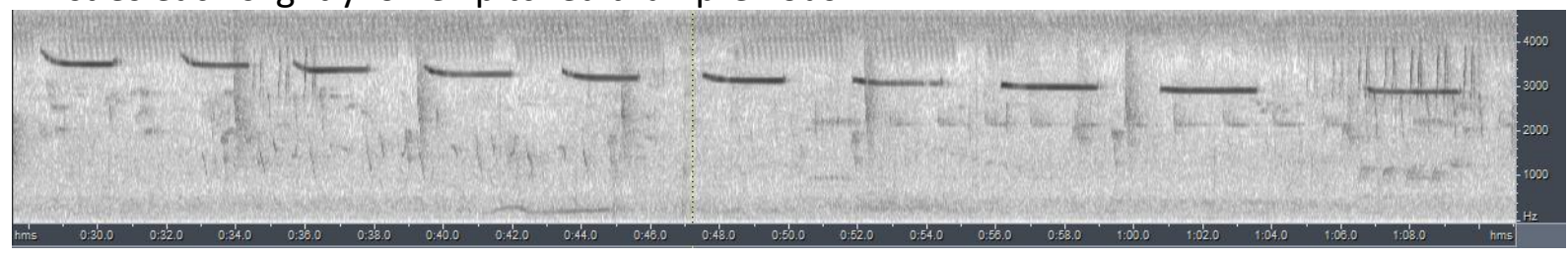




\section{HANDBOOK OF THE \\ BIRDSPF THE WORLD \\ Alue}

\section{ORNITHOLOGICAL NOTES}

\section{$\underline{\text { brevirostris }}$}

short song: long flat-pitched whistles:

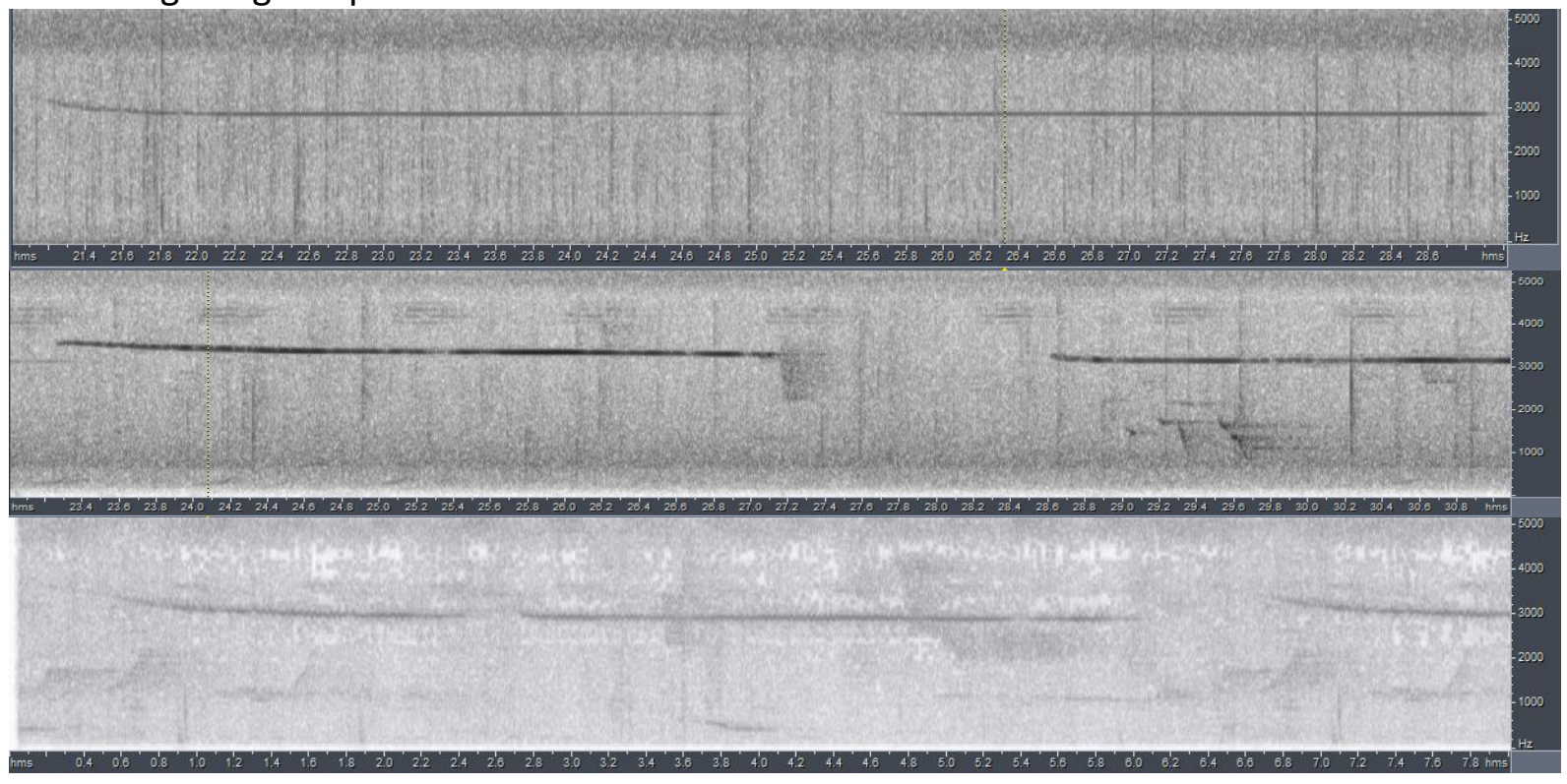

\section{superciliaris}

short song: fairly short up- or downslurred whistles and distinct burry to scratchy notes:

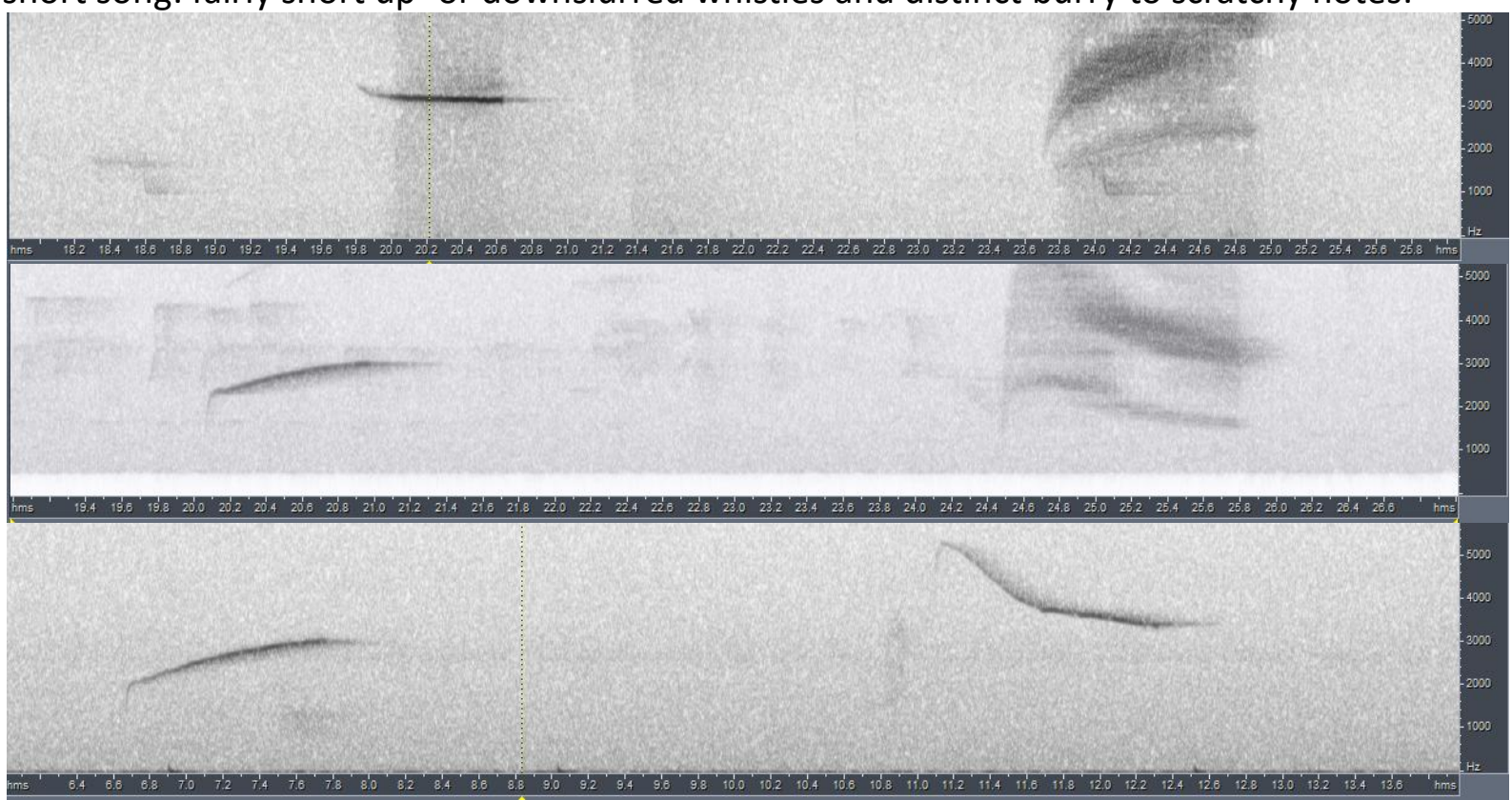

full song: series of short whistles:

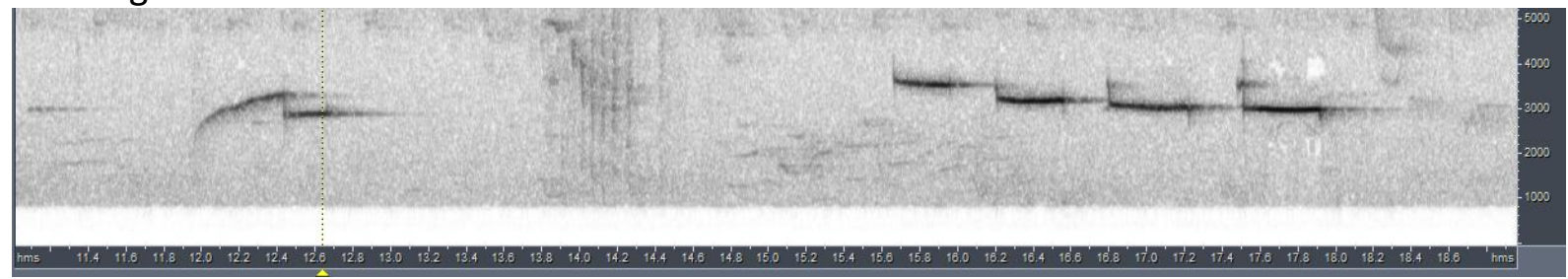



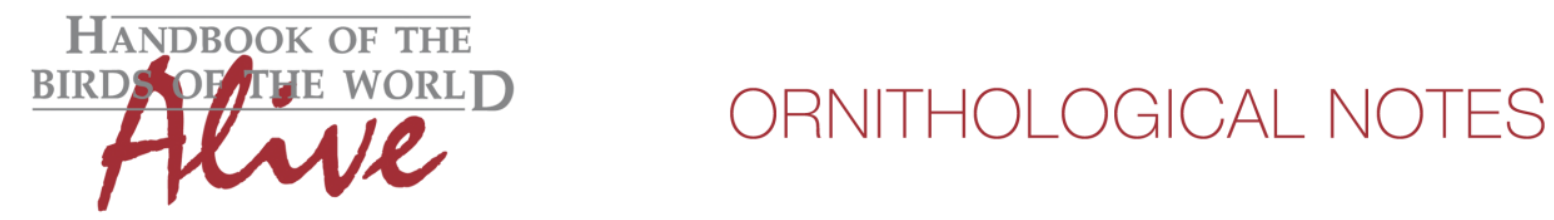

From the above it would seem that especially Australian superciliaris is vocally distinct.

Beehler (2016) describes song in New Guinea as a slow series of about 5 high-pitched minor key drawn-out whistles $(1 / \mathrm{s})$, each note dropping slightly, then maintaining pitch in the final segment (compare with 3rd sonogram for nigriceps).

With the remark that there are relatively few recordings, voice of superciliaris could be scored against all other races for its much shorter whistles (score 2-3), different vocabulary with distinct burry notes (score 1) and larger frequency range (especially of the burry notes, but also the whistles) (score 2). When applying Tobias criteria this would lead to a total vocal score of 4-5.

Differences between the other races are much less pronounced, one would need a higher number of recordings to confirm any consistent differences (e.g. the rhythmic delivery with long and short whistles of beccarii could be a distinguishing feature).

This note was finalized on 2nd February 2016, using sound recordings available on-line at that moment. We would like to thank in particular the sound recordists: Patrik Åberg, Nick Athanas, Niels Poul Dreyer, David Gibbs, Henk Krajenbrink, Eliot Miller, John V Moore, Andrew Spencer, Eric Tan, Fred Van Gessel and lain Woxvold.

\section{References}

Beehler, B.M. \& Pratt, T.K. (2016). Birds of New Guinea: Distribution, Taxonomy, and Systematics. Princeton University Press, Princeton, New Jersey.

Tobias, J.A., Seddon, N., Spottiswoode, C.N., Pilgrim, J.D., Fishpool, L.D.C. \& Collar, N.J. (2010). Quantitative criteria for species delimitation. Ibis 152(4): 724-746.

\section{Recommended citation}

Boesman, P. (2016). Notes on the vocalizations of Northern Scrub-robin (Drymodes superciliaris). HBW Alive Ornithological Note 214. In: Handbook of the Birds of the World Alive. Lynx Edicions, Barcelona. (retrieved from http://www.hbw.com/node/932172 on 6 September 2016). 